\title{
DISTRIBUSI JENIS IKAN DAN KUALITAS PERAIRAN DI BENGAWAN SOLO
}

\author{
Agus Djoko Utomo", Susilo Adjie "), Niam Muflikah"), dan Arif Wibowo")
}

\begin{abstract}
ABSTRAK
Bengawan Solo merupakan sungai yang sudah banyak mengalami perubahan seperti waduk, bendungan, sodetan, dan lain-lain. Bengawan Solo melewati Propinsi Jawa Tengah dan Timur yang padat penduduk, sekitar 15,2 juta jiwa tinggat di satuan wilayah Sungai Bengawan Solo dan banyak terdapat industri. Permasalahan tersebut dapat berpengaruh langsung terhadap kehidupan organisme air. Kajian tentang sumber daya ikan dan pengamatan lingkungan perairan diharapkan dapat memberikan informasi tentang status perikanan dan kualitas perairan di Bengawan Solo. Parameter yang diamati dalam penelitian ini adalah distribusi jenis ikan, kualitas air, dan hasil tangkapan nelayan. Contoh ikan dikumpulkan dari hasil tangkapan nelayan dengan berbagai macam alat pada stasiun penelitian yang telah ditetapkan, mewakili ruas sungai bagian hulu, tengah, dan hilir. Selain dilakukan pemeriksaan kualitas air pencatatan hasil tangkapan juga dilakukan terhadap nelayan responden pada tiap stasiun penelitian. Di sepanjang Bengawan Solo telah ditemukan lebih dari 40 jenis ikan. Ikan tebaran seperti ikan nila (Oreohcromis niloticus), jambal sius (Pangasius hypophthalmus), tawes (Barbodes gonionotus) banyak terdapat di Waduk Gajah Mungkur Wono Giri. Di Bengawan Solo bagian tengah yaitu Solo, Sragen, dan di sekitar banyak terdapat ikan sapu-sapu (Liposarcus pardalis). Ada indikasi bahwa Bengawan Solo di daerah Solo, Sragen, dan di sekitar telah tercemar berat dengan kualitas air buruk yaitu oksigen rendah (0 sampai dengan $\left.9,54 \mathrm{mg} \mathrm{I}^{-1}\right)$, karbon dioksida tinggi $\left(9,33\right.$ sampai dengan $\left.34,32 \mathrm{mg} \mathrm{l}^{-1}\right)$, amonia tinggi $\left(0,1\right.$ sampai dengan $\left.21,67 \mathrm{mg} \mathrm{r}^{-1}\right)$, COD tinggi (16 sampai dengan $172 \mathrm{mg} \mathrm{l}^{-1}$ ), fenol tinggi $\left(0,238\right.$ sampai dengan $\left.0,1,431 \mathrm{mg} \mathrm{l}^{-1}\right)$, dan minyak lemak tinggi $(8,7$ sampai dengan $54,6 \mathrm{mg}$ $r^{-1}$ ). Di Bengawan Solo bagian hilir yaitu Bojonegoro, Tuban, Babat, dan di sekitar, banyak jenis ikan asli yaitu jambal lokal (Pangasius jambal), tagih (Mystus nemurus), wagal (Pangasius micronema), lumbet (Cryptopterus spp.), dan lain-lain.
\end{abstract}

KATA KUNCI: distribusi jenis ikan, kualitas perairan, sungai, Bengawan Solo

\section{ABSTRACT: Fish distribution and water quality in Solo River. By: Agus Djoko Utomo, Susilo Adjie, Ni'am Muflikah, and Arif Wibowo}

Bengawan Solo River is highly modified by dams, impoundment, reservoir, channelization and etc. It traverses Central Java and East Java Province in its passage from headwaters to the sea. Many industries and heavy population (approximately 15.2 million people) near the river have gread potency to insluence the organisms cury in the river. Study on fisheries resources and water quality is expected to provide current information on fishery status and aquatic environment condition in Bengawan Solo River. Parameters observed in the study were fish distribution, waters quality and catehes produced by multifishing gear from fisherman. Fishes sample were collected from similar study sites with the site for recording the catch of fisherman. The selected study sites represent upper, middle, and lower reaches of Bengawan Solo River. Water conditions in various study sites were examined. Results show that more than 40 fishes species were found in Bengawan Solo River. The exotic species such as nile tilapia (Oreochromis niloticus), jambal sius (Pangasius hypophthalmus), tawés (Barbodes gonionotus) are commonly found in the upper reaches of the river system. Sapu-sapu (Liposarcus pardalis) is frequently found in middle reaches of the river (Solo, Sragen). An overview of water quality in the middle of Bengawan Solo River indicates that the segments is already heav polluted as indicated by dissolved low oxygen (0 to $9.54 \mathrm{mg} \mathrm{r}^{1}$ ) and high concentiations of $\operatorname{CO} 2(9.33$ to 34.32$)$, ammonia $\left(0.1\right.$ to $\left.21.67 \mathrm{mg}^{\prime}\right)$, COD (16 to $\left.172 \mathrm{mg} r^{1}\right)$, phenol $\left(0.238\right.$ to $\left.0.1431 \mathrm{mg} r^{1}\right)$, also oil and grease $\left(8.7\right.$ to $\left.54.6 \mathrm{mg} r^{t}\right)$. Native species such as jambal (Pangasius jambal), tagih (Mystus nemurus), wagal (Pangasius micronema), lumbet (Cryptopterus'spp.) are normally found in the lower part of Bengawan Solo River system (Babat Region, Tuban).

KEYWORDS: fish distribution, water quality, river, Bengawan Solo

\footnotetext{
Peneliti pada Balai Riset Perikanan Perairan Umum, Mariana-Palembang
} 


\section{PENDAHULUAN}

Bengawan Solo merupakan sungai terpanjang di Pulau Jawa $(600 \mathrm{~km})$, melintasi 2 propinsi yaitu Jawa Tengah dan Jawa Timur dengan luas daerah pengaliran $16.000 \mathrm{~km}^{2}$ (Anonim, 1997). Bengawan Solo mempunyai arti penting bagi pertanian, perikanan, pariwisata, perkebunan, masyarakat, dan kehidupan organisme air. Apabila dibandingkan dengan sungai yang lain seperti Sungai Musi, Sungai Kapuas, dan Sungai Barito, maka Bengawan Solo merupakan contoh sungai yang telah banyak mengalami modifikasi dan padat penduduk di sekeliling.

Beberapa tipe modifikasi yang mempengaruhi bentuk keaslian Bengawan Solo antara lain waduk, bendungan, sodetan, penimbunan rawa, dan lainIain. Beberapa bentuk bendungan besar yang ada di sepanjang bengawan Solo antara lain di Colo (Sukaharjo), Karang Nongko (Ngawi), Bojonegoro, Babat (Tuban), Sembayat (Lamongan), dan lainlain. Beberapa waduk yang di aliran Bengawan Solo antara lain Waduk Gajah Mungkur (Wonogiri), Waduk Botok (Sragen), Waduk Gebyar (Sragen), dan bentuk sodetan (floodway) di Jabung (Tuban).

Waduk, bendungan, dan sodetan dibangun untuk kepentingan irigasi ke Iahan pertanian, penanggulangan banjir, pembangkit tenaga listrik, dan lain-lain. Sebagai contoh Waduk Gajah Mungkur Wonogiri dapat mengairi sawah seluas 33.200 ha dan pembangkit tenaga listrik 12,4 MW, dapat mengurangi banjir di daerah Solo, Sragen serta sebagai sumber daya air minum (Anonim, 1992). Dari segi perikanan, Waduk Gajah Mungkur juga mempunyai arti penting, sebagai contoh pada tahun 2003 produksi ikan pada karamba jaring apung 882,8 ton (Anonim, 2003). Di samping dampak positif, modifikasi badan air juga menimbulkan dampak negatif antara lain penurunan jumiah keragaman jenis atau perubahan jenis organisme air, penurunan volume air di bagian hilir dan lain-lain.

Kepadatan penduduk di sepanjang sungai sedikit banyak akan berpengaruh terhadap kondisi lingkungan perairan sungai, sekitar 15,2 juta jiwa tinggal di satuan wilayah Sungai Bengawan Solo. Pembuangan limbah oleh penduduk ke sungai akan menimbulkan pencemaran bahan organik di perairan. Di sekitar Solo telah banyak industri (kurang lebih ada 50 pabrik) yang antara lain pabrik tekstil, alkohol, penyamakan kulit, mono sodium glutamat, dan lain láin. Limbah industri berupa bahan organik maupun anorganik dan sebaik limbah yang dibuang ke sungai harus d olah lebih dahulu agar tidak mencemari sungai.
Ikan hidup dalam media air sehingga perubahan lingkungan perairan akan berdampak langsung terhadap kehidupan ikan.

Penelitian ini bertujuan untuk mendapatkan data tentang sebaran jenis ikan, hasil tangkapan nelayan dan kualitas perairan Bengawan Solo di Jawa Tengah dan Jawa Timur. Diharapkan penelitian tersebut dapat memberikan informasi tentang status keragaman jenis ikan, status perikanan tangkap dan kualitas perairan di Bengawan Solo. Informasi tersebut diharapkan dapat memberikan masukan untuk pengelolaan sumber daya perairan dan perikanan di Bengawan Solo.

\section{BAHAN DAN METODE}

Penelitian dilakukan pada bulan April sampai dengan bulan Desember 2004 di Bengawan Solo Propinsi Jawa Tengah dan Jawa Timur. Survei ke lapangan dilakukan 5 kali yaitu pada bulan Mei, Agustus, September, Oktober, dan Desember 2004. Parameter yang diamati meliputi jenis ikan, kualitas air (lihat Tabel 1), jenis alat tangkap dan hasil tangkapan. Di samping itu, juga dilakukan pencatatan data sekunder terutama yang berkaitan dengan keadaan umum daerah.

Stasiun pengamatan yang dipilih meliputi ruas hulu sampai dengan hilir yaitu ruas hulu yang meliputi Waduk Gajah Mungkur dan di sekitar (inlet waduk Sungai Keduang di Watu Pecah, outlet waduk dekat Pusat Listrik Tenaga Air, dalam waduk di Kedung Jati), dan Bendung, Colo (Sukaharja). Bagian tengah meliputi Juruk (Solo), Tenggak (Sragen), dan Cemeng (Sragen). Bagian hilir meliputi Ngablak, Karang Binangun, dan Ujung Pangkah (Gambar 1).

Pengumpulan spesimen ikan diambil dari hasil tangkapan nelayan dengan menggunakan berbagai macam alat tangkap (jaring, jala, stroom, cerok, dan pancing). Pengumpulan spesimen ikan dilakukan pada saat survei ke lapangan. Ikan dicatat nama lokal, tempat tertangkap, waktu penangkapan, ukuran, dipotret, dan dimasukkan dalam kantong plastik selanjutnya disimpan dalam cool box yang selalu berisi es untuk dibawa ke laboratorium. Ikan diidentifikasi di laboratorium berdasarkan pada kunci identifikasi dari Kottelat et al. (1993); Weber \& De Beaufort (1916); Gustiano (2003).

Data hasil tangkapan nelayan dikumpulkan dari nelayan yang telah ditetapkan sebagai responden. Pada tiap stasiun pengamatan diambil 2 nelayan 


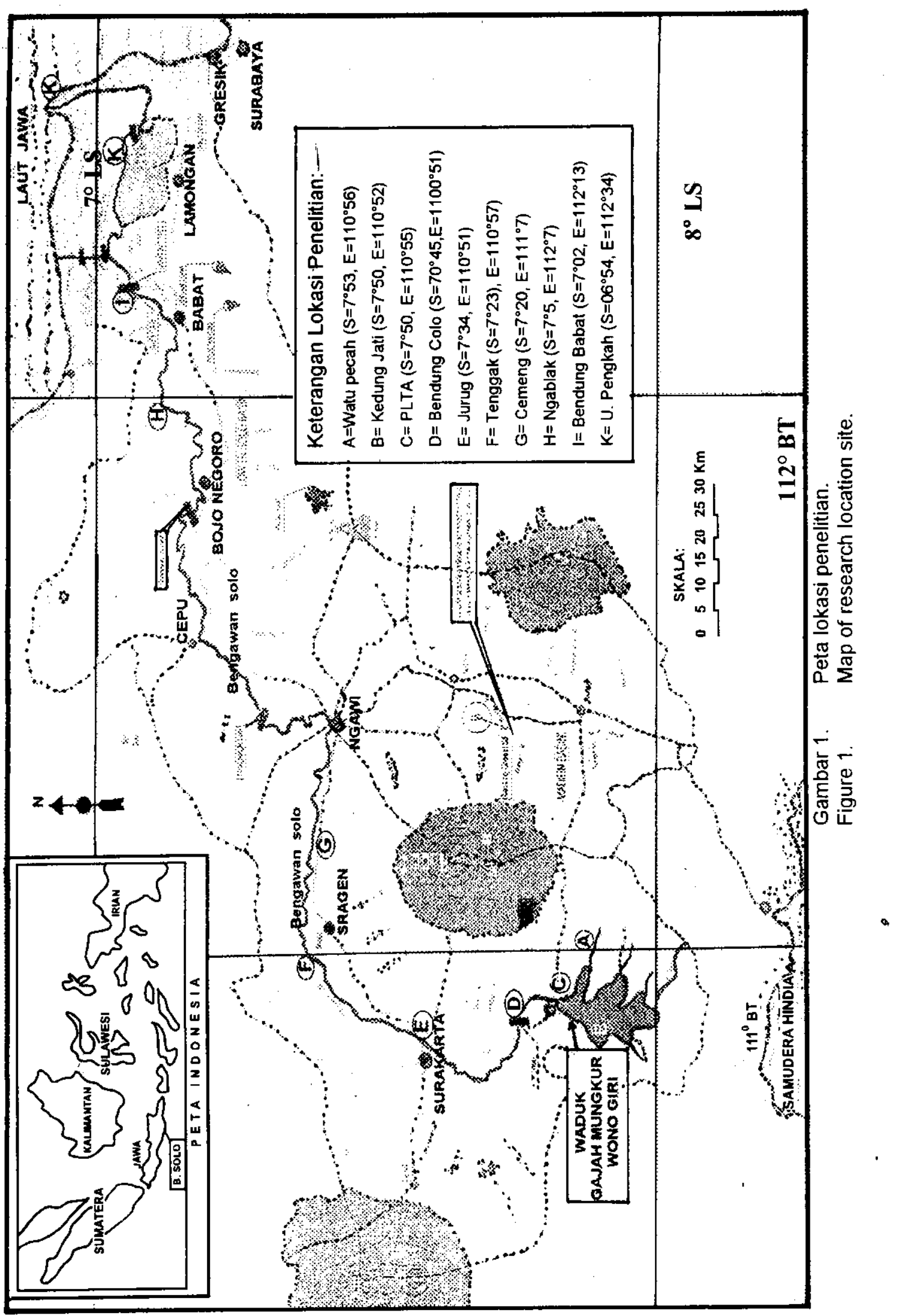


Tabel 1. Parameter dan metode analisis contoh air Table 1. Parameters and methods of water sample analysis

\begin{tabular}{|c|c|c|}
\hline Parameter/Parameter & Satuan/Unit & Metode dan peralatan/Méthod and instrument \\
\hline 1. Suhu & ${ }^{\circ} \mathrm{C}$ & Insitu, termometer \\
\hline 2. Kecerahan & $\mathrm{cm}$ & Insitu, piring sechi \\
\hline 3. $\mathrm{DHL}$ & $\mu S / \mathrm{cm}$ & Insitu, SCT meter \\
\hline 3. $\mathrm{pH}$ & $\mathrm{pH}$ unit & Insitu, pH universal indicator \\
\hline 4. Karbondioksida & $\mathrm{mg} \mathrm{l}^{-1}$ & Insitu, metode Winkler, titrimetri dengan $\mathrm{NaOH}$ sebagai titrant \\
\hline 5. Oksigen terlarut & $\mathrm{mg} \mathrm{l}^{-1}$ & $\begin{array}{l}\text { Insitu, metode Winkler, titrimetri dengan larutan thiosulfat } \\
\text { sebagai titrant }\end{array}$ \\
\hline 6. Alkalinitas & $\mathrm{mg} \mathrm{l}^{-1}$ & $\begin{array}{l}\text { Insitu, metode Winkler, titrimetri dengan Iarutan } \mathrm{H}_{2} \mathrm{SO}_{4} \text { sebagai } \\
\text { titrant }\end{array}$ \\
\hline 7. $\mathrm{BOD}$ & $\mathrm{mg} \mathrm{l}^{-1}$ & $\begin{array}{l}\text { Insitu, metode Winkler, titrimetri dengan larutan thiosulfat } \\
\text { sebagai titrant }\end{array}$ \\
\hline 8. $\mathrm{PO}_{4}$ & $\mathrm{mg} \mathrm{l}^{-1}$ & Metode Vanadate molibdate, spectrophotometric \\
\hline 9. $\mathrm{NO}_{3}$ & $\mathrm{mg} \mathrm{l}^{-1}$ & Metode Nessler, spectrophoto metric \\
\hline 10. $\mathrm{NO}_{2}$ & $\mathrm{mg} \mathrm{l}^{-1}$ & Metode Nessler, spectrophoto metric \\
\hline 11. COD & $\mathrm{mg} \mathrm{l}^{-1}$ & $\begin{array}{l}\text { Metode Dichromate Reflux, titrimetri dengan standard ferrous } \\
\text { ammonium sulfat sebagai titrant }\end{array}$ \\
\hline 12. $\mathrm{N}-\mathrm{NH}_{3}$ & $\mathrm{mg} \mathrm{l}^{-1}$ & Metode Phenate, spectrophoto metric \\
\hline 13. Fenol & $\mathrm{mg} \mathrm{l}^{-1}$ & Metode extrasi khloroform, spectro photometric \\
\hline 14. Minyak lemak & $\mathrm{mg} \mathrm{|}^{-1}$ & $\begin{array}{l}\text { Metode Kjeldahl, gravimetri, exterasi petroleum, spectropho } \\
\text { tometric }\end{array}$ \\
\hline
\end{tabular}

responden, alat tangkap yang digunakan adalah jaring, jala, dan penggunaan listrik. Pengumpulan data hasil tangkapan dilakukan dengan cara wawancara dan pengisian blanko isian, sebelum penelitian responden telah dilatih cara pengisian blanko. Untuk mengetahui kecenderungan produksi perikanan tangkap 5 tahun terakhir atau lebih, maka dilakukan wawancara dengan nelayan yang mempunyai pengalaman lebih dari 5 tahun.

Parameter kualitas air yang diukur pada saat melakukan survei yaitu suhu, kecerahan, $\mathrm{DHL}, \mathrm{pH}$, karbondioksida, oksigen terlarut, alkalinitas, dan $B O D_{5}$. Parameter kualitas air yang diamati di laboratorium yaitu fosfat, nitrit, nitrat, amonia, phenol, dan minyak lemak, maka dalam perjalanan harus disimpan dalam cool box. Pengamatan kualitas air berdasarkan pada APHA 1986 (Tabel 1).

Data jenis ikan, hasil tangkapan, kualitas air pada tiap stasiun dibuat tabulasi data sehingga akan terlihat sebaran ikan pada perbedaan habitat, perbedaan hasil tangkapan, dan komposisi hasil tangkapan pada tiap habitat, perbedaan nilai parameter kualitas air pada tiap habitat. Data hasil tangkapan 5 tahun terakhir dibuat grafik histogram, sehingga akan kelihatan trend selama 5 tahun terakhir.

\section{HASIL DAN BAHASAN}

\section{Kualitas Perairan}

Perairan Bengawan Solo terutama pada beberapa wilayah tengah menunjukkan indikasi telah tercemar yang cukup serius (Tabel 2). Nilai COD di Desa Cemeng (Kabupaten Sragen) mencapai $127,5 \mathrm{mg} \mathrm{I}^{-1}$. Perairan yang tidak tercemar nilai COD kurang dari $20 \mathrm{mg} \mathrm{I}^{-1}$ (UNESCONHO/UNEP yang dikutip oleh Effendi, 2000). Nilai COD yang tinggi menggambarkan banyak pencemaran kimiawi organik yang dapat menurunkan kandungan oksigen di perairan sehingga akan mengganggu pernapasan organisme air.

Nilai oksigen terlarut di Desa Tenggak (Kabupaten Sragen) terendah 1,94 $\mathrm{mg} \mathrm{I}^{-1}$, bahkan di Desa Cemeng (Kabupaten Sragen) pernah tercatat mendekati $0 \mathrm{mg} \mathrm{l}^{-1}$. Kandungan oksigen di perairan yang baik untuk organisme air baik lebih dari $4 \mathrm{mg} \mathrm{l}^{-1}$, sedangkan oksigen terlarut kurang dari $2 \mathrm{mg} \mathrm{I}^{-1}$ dapat menyebabkan kematian beberapa jenis ikan. Kandungan oksigen rendah di suatu perairan dapat disebabkan oleh reduksi oksigen dari bahan pencemar yang masuk ke perairan. Menurut informasi dari masyarakat setempat di perairan Desa Tenggak dan Desa 
Cemeng dalam 1 bulan terjadi 3 sampai dengan 4 kali pencemaran yang serius, yang menyebabkan air sangat berbau (sengak) dan ikan banyak yang mengapung (mabuk). Kejadian ini oleh masyarakat setempat diberi istilah pladu.

Nilai karbondioksida di Jurug (Solo), Desa Tenggak dan Cemeng menunjukkan tingkat tertinggi yaitu masing-masing $14,44 \mathrm{mg} \mathrm{l}^{-1}, 12,32$ $\mathrm{mg} \mathrm{l}^{-1}$, dan $34,32 \mathrm{mg} \mathrm{l}^{-1}$. Karbondioksida $\left(\mathrm{CO}_{2}\right)$ yang tinggi di perairan bersifat racun bagi ikan, karena dapat mengganggu pernapasan. Konsentrasi karbondioksida baik kurang dari $5 \mathrm{mg}$ $r^{-1}$, karena konsentrasi lebih dari $10 \mathrm{mg} \mathrm{I}^{-1}$ yang disertai dengan oksigen yang rendah dapat menyebabkan kematian beberapa jenis ikan. Kandungan karbondioksida yang tinggi dapat disebabkan oleh hasil dekomposisi bahan pencemaran di perairan.

Kandungan fenol di Desa Tenggak dan Cemeng masing-masing 0,238 sampai dengan $1,431 \mathrm{mg} \mathrm{l}^{-1}$ dan $0,259 \mathrm{mg}^{-1}$. Kadar fenol di perairan alami sangat kecil, sumber fenol berasal dari hasil limbah industri. Kadar fenol lebih dari $0,01 \mathrm{mg} \mathrm{I}^{-1}$ bersifat toksik bagi ikan dan mengakibatkan perubahan sifat organoleptik air (UNESCOMHO/UNEP yang dikutip oleh Effendi, 2000).

Kandungan minyak lemak pada beberapa stasiun pengamatan seperti Bendung, Colo (Kabupaten Sidoarjo) $=9,3 \mathrm{mg} \mathrm{l}^{-1}$, Juruk (Solo) $=8,6$ $\mathrm{mg} \mathrm{l}^{-1}$, Tenggak (Sragen) $=8,7$ sampai dengan 54,6 $\mathrm{mg} \mathrm{l^{-1 }}$, Cemeng (Sragen) $=25,6 \mathrm{mg} \mathrm{l}^{-1}$, dan Ngablak (Tuban) $=6,7 \mathrm{mg} \mathrm{I}^{-1}$. Keberadaan minyak lemak di perairan berasal dari limbah domestik ataupun industri, kadar minyak lemak lebih dari $0,3 \mathrm{mg} \mathrm{l}^{-1}$ bersifat toksik bagi beberapa jenis ikan air tawar (UNESCOMHO/UNEP yang dikutip oleh Effendi, 2000).

Kandungan amonia $\left(\mathrm{N}-\mathrm{NH}_{3}\right)$ pernah tercatat cukup tinggi pada beberapa stasiun yaitu di Bendung, Colo $=3,48 \mathrm{mg} \mathrm{l}^{-1}$, Gedung, Jati $=4,08 \mathrm{mg}$ $\mathrm{r}^{-1}$, Kali Bengawan (inlet $)=3,914 \mathrm{mg} \mathrm{l}^{-1}$, Hilir Waduk

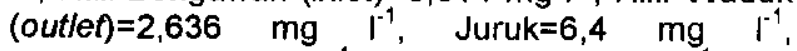
Tenggak $=21,67 \mathrm{mg} \mathrm{l}^{-1}$, Cemeng $=19,05 \mathrm{mg} \mathrm{l}^{-1}$, dan Ngablak=4, $14 \mathrm{mg} \mathrm{l}^{-1}$. Kadar amonia di perairan dapat berasal dari proses dekomposisi bahan pencemaran organik. Kandungan amonia yang tinggi di perairan merupakan indikasi ada pencemaran bahan organik di perairan, kadar amonia bebas melebihi $0,2 \mathrm{mg}^{-1}$ dapat menyebabkan kematian beberapa jenis ikan (Sawyer \& McCarty dalam Effendi, 2000).

Menurut informasi dari www.Liputan6.com tanggal 15 Agustus 2004 Pusat Penelitian Universitas Negeri Sebelas Maret, Surakarta, Jawa Tengah menemukan ada indikasi bahwa Bengawan Solo tercemar cadmium dan cromium, kandungan sudah diambang batas. Pencemaran tersebut telah berdampak pada komoditi pertanian seperti padi, palawija, dan air untuk kebutuhan rumah tangga. Kadar cromium sudah mencapai 3,8 sampai dengan $7,5 \mathrm{mg}$ per $\mathrm{kg}$ padi, padahal ambang batas hanya $2,5 \mathrm{mg}$ per $\mathrm{kg}$.

\section{Sebaran Jenis Ikan}

\section{Stasiun Wilayah Hulu (Wonogiri, Sukohardjo)}

Selama penelitian telah didapat 40 jenis ikan di sepanjang Bengawan Solo, pada wilayah hulu ada 20 jenis ikan (Tabel 3), Purnomo (2000) mengatakan bahwa di Waduk Gajah Mungkur Wonogiri terdapat 15 jenis ikan. Jenis ikan introduksi banyak ditemukan di Waduk Gajah Mungkur (Wonogiri) antara lain nila (Oreochromis niloticus), jambal sius (Pangasius hypophthalmus), tawes (Barbodes gonionotus) (Lampiran 1). Ikan nila dan tawes dapat tumbuh dan berkembang dengan baik di Waduk Gajah Mungkur disebabkan oleh ikan tersebut dapat memanfaatkan relung ekologi banyak tumbuhan air (Purnomo, 2000). Di sisi lain jambal sius dapat tumbuh dan berkembang dengan baik karena di Waduk Gajah Mungkur banyak tersedia pakan alami yang sesuai yaitu plankton dan detritus (Purnomo et al., 2003).

Jenis ikan asli yang sering didapat di Waduk Gajah Mungkur yaitu sogo (Mystus nemurus), lukas (Dangila cuverii), nilem (Osteochilus hasselti), dan beberapa jenis ikan asli yang kadang-kadang didapatkan yaitu betutu (Oxyeleotris marmorata), gabus (Channa striata), karper lumut (Osteochilus schlegell), keprek merah (Barbodes sp.) (Lampiran 2). Menurut Purnomo (2000) mengatakan bahwa hasil tangkapan ikan lalawak (Barbodes bramoides) pada tahun 1999 menempati urutan ke- 6 , sedangkan berdasarkan pada hasil penelitian sekarang ikan tersebut jarang tertangkap. Begitu juga menurut Juhro (1989) mengatakan bahwa ikan genggehek (Mystacoleucus marginatus) sering tertangkap walaupun jumlah relatif sedikit, namun berdasarkan pada hasil penelitian sekarang ikan tersebut tidak ditemukan. Pada stasiun pengamatan di Bendung, Colo (Sukoharjo) ikan yang kadang-kadang didapatkán antara lain wader pari (Rasbora spp.), tawes (Barbodes gonionotus), dan sogo (Mystus nemurus).

\section{Wilayah Tengah (Sukohardjo, Sragen)}

Pada wilayah tengah terdapat 13 jenis ikan. Pada stasiun pengamatan Juruk, Solo sering 


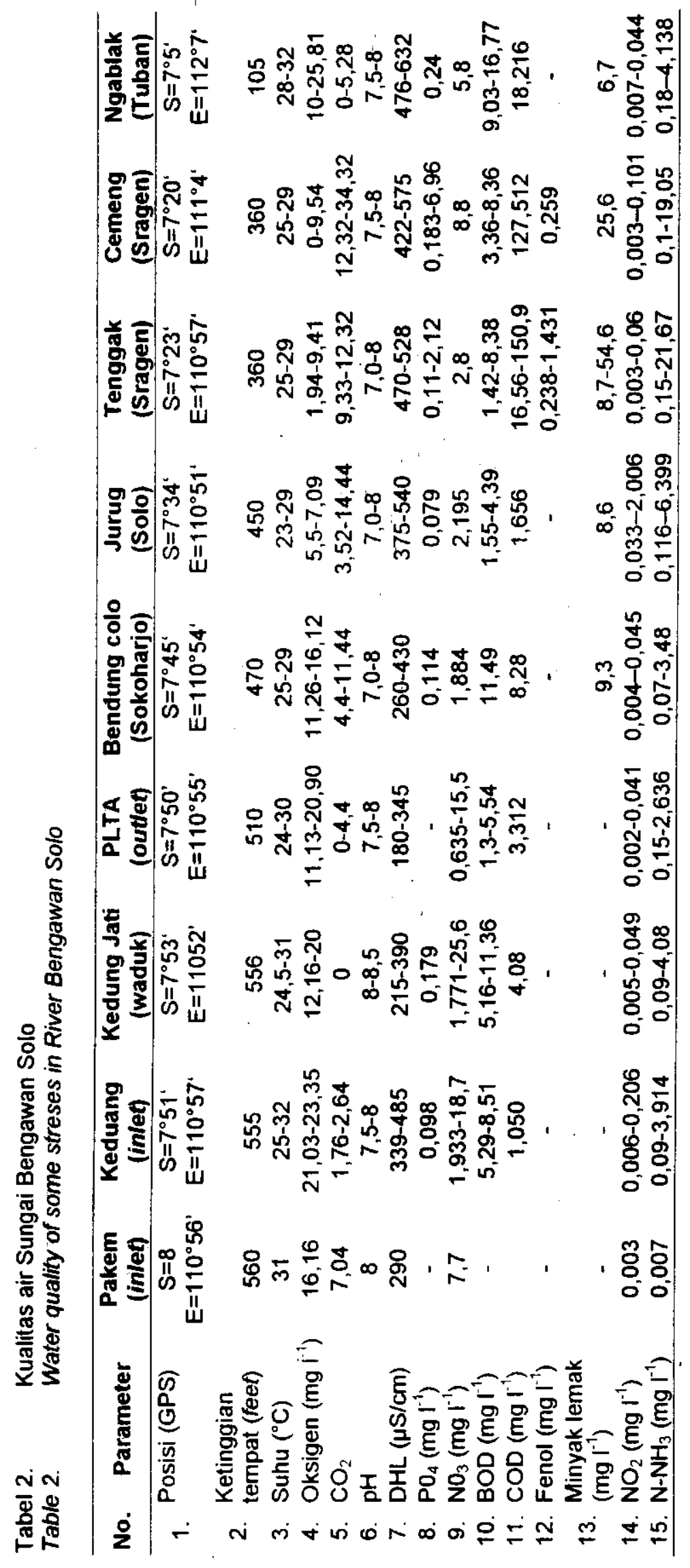


Tabel 3. Sebaran Jenis ikan di Bengawan Solo

Table 3. Distribution of fishes species in Bengawan Solo River

\begin{tabular}{|c|c|c|c|c|c|}
\hline \multirow{2}{*}{ Family } & \multirow{2}{*}{ Nama Lokal } & \multirow{2}{*}{ Nama IImiah } & \multicolumn{3}{|c|}{ Zona } \\
\hline & & & Hulu & Tengah & Hilir \\
\hline \multirow[t]{14}{*}{ 1. Cyprinidae } & Arengan & Labeo chrysophekadion & - & - & + \\
\hline & Bader/tawes & Barbodes gonionotus & ++++ & + & ++ \\
\hline & Bader & Cyclocheilichthys enoplos & $\cdots$ & + & + \\
\hline & Bangbangan & Barbodes schwanefeldii & - & + & - \\
\hline & Bendol & Barbichthys laevis & - & - & +++ \\
\hline & $\begin{array}{l}\text { Karper lumut } \\
\text { Lalawak }\end{array}$ & $\begin{array}{l}\text { Osteochilus schlegeli } \\
\text { Barbodes sp. }\end{array}$ & $\begin{array}{l}+ \\
+\end{array}$ & - & - \\
\hline & Lempik & Parachela oxygastroides & + & - & - \\
\hline & Lingkasan/lukas & Dangila cuvieri & ++ & - & + \\
\hline & Nilem & Osteochilus hasselti & + & - & - \\
\hline & Palung & Hampala macrolepidota & + & - & - \\
\hline & Seren & Cyclocheilichthis sp. & - & - & + \\
\hline & Keprek abang & Barbodes sp. & + & - & - \\
\hline & Wader & Rasbora spp. & + & + & + \\
\hline & Wader & Mystacoleucus marginatus & - & - & + \\
\hline 2. Anabantidae & Betik & Anabas testudineus & - & - & + \\
\hline 3. Eleotridae & Betutu & Oxyeleotris marmorata & + & + & + \\
\hline 4. Gobiidae & Bloso & Callogobius hasselti & - & - & + \\
\hline \multirow[t]{4}{*}{ 5. Bagridae } & Garingan & Mystus microcanthus & - & - & +++ \\
\hline & & Mystus nigriceps & - & - & + \\
\hline & Keting & Mystus planiceps & - & - & ++ \\
\hline & Sogo/tagih & Mystus nemurus & +++ & + & ++ \\
\hline \multirow[t]{3}{*}{ 6. Pangasidae } & Jambal sius ${ }^{\star}$ & Pangasius hypopthalmus & $++t+$ & - & - \\
\hline & Jambal lokal & Pangasius jambal & - & - & + \\
\hline & Wagal/jendil & Pangasius micronema & - & - & +++ \\
\hline 7. Channidae & Kutuk & Channa striata & + & + & + \\
\hline 8. Chanidae & Bandeng & Chanos chanos & - & - & + \\
\hline 9. Synbranchidae & Belut & Fluta alba & + & + & + \\
\hline 10. Claridae & Lele & Clarias spp. & + & + & + \\
\hline 11. Notopteridae & Lemper & Notopterus notopterus & - & - & + \\
\hline \multirow[t]{2}{*}{ 12. Siluridae } & Lempuk & Ompok bimaculatus & $=$ & - & + \\
\hline & Lumbet & Cryptopterus spp. & - & - & + \\
\hline \multirow[t]{2}{*}{ 13. Cichlidae } & Mujair**) & Oreochromis mossambicus & - & + & ++ \\
\hline & Nila*) & Oreochromis niloticus & ++++ & + & - \\
\hline 14. Loricaridae & Sapu-sapu & Liposarcus pardalis & - & ++++ & ++ \\
\hline \multirow[t]{2}{*}{ 15. Belontiidae } & Sepat siam & Trichogaster pectoralis & - & - & ++ \\
\hline & Sepat rawa & Trichogaster tricopterus & - & - & +++ \\
\hline 16. Mastacembelidae & Sili & Macrognathus aculeatus & - & - & + \\
\hline 17. Palaemonidae & Udang galah & Macrobrachium rosenbergii & - & - & + \\
\hline \multirow[t]{2}{*}{ 18. Sergestidae } & Udang & Metapenaeus monoceros & + & - & + \\
\hline & Udang & Metapenaeus brevicornis & + & - & + \\
\hline
\end{tabular}

\section{Keterangan/Remarks:}

$++++=$ Hampir tiap hari tertangkap, hasil $\geq 2 \mathrm{~kg}$ per hari per orang

$+++=$ Hampir tiap hari tertangkap, hasil 1 sampai dengan $2 \mathrm{~kg}$ per hari per orang

$+\quad=$ Tidak tiap hari tertangkap, hasil 0,5 sampai dengan $4 \mathrm{~kg}$ per hari per orang

$+\quad=$ Jarang tertangkap, hasil $\leq 0,5 \mathrm{~kg}$ per hari per orang

*) = ikan tebaran

-*) = ikan terlepas dari tambak atay kolam

- $\quad=$ Lokasi pengambilan contoh ikan di wilayah hulu yaitu Keduang Jati (Waduk Gajah Mungkur), Watu Pecah (Waduk Gajah Mungkur), dan Bendung Colo (Sukohardjo)

= Lokasi pengambilan contoh ikan di wilayah tengah yaitu Jurug (Solo) dan Cemeng (Sragen)

- $\quad$ = Lokasi pengambilan contoh ikan di wilayah hilir yaitu Ngablak (Tuban), Babat, dan Karang Binagun (Lamongan) 
terdapat ikan kutuk (Channa striata), lele (Clarias spp.), dan mujair (Oreochromis mossambicus). Ikan mujair berasal dari ikan yang terlepas dari kegiatan usaha budi daya ikan di kolam. Berdasarkan pada hasil pengambilan contoh dari nelayan di stasiun pengamatan Desa Tenggak dan Cemeng, Sragen jenis ikan yang dominan adalah ikan sapu-sapu (Liposarcus pardales), yaitu jenis ikan yang tahan terhadap pencemaran. Pada saat tertentu, terutama sehabis hujan turun pencemaran datang bersama datang air, maka banyak ikan mabuk antara lain ikan tawes (Barbodes gonionotus), daringan (Mystus nigriceps), dan tagih (Mystus nemurus).

\section{Wilayah Hilir (Sragen, Lamongan)}

Pada wilayah hilir terdapat 33 jenis ikan. Pada stasiun pengamatan di Desa Ngablak dan Simorejo (Tuban, Jawa Timur) banyak terdapat ikan lokal yang bernilai ekonomis penting yaitu wagal (Pangasius micronema), tawes (Barbodes gonionotus), tagih (Mystus nemurus), jambal (Pangasius jambal), lumbet (Cryptopterus spp.), lemper (Notopterus notopterus), bendol (Barbichthys laevis), seren (Cyclocheilichthys sp.), betutu (Oxyeleotris marmorata), kutuk (Channa striata), sepat (Trichogaster trichopterus), dan sili (Macrognathus aculeatus). Jenis ikan besar antara lain jambal dan tagih banyak ditemukan di lubuklubuk sungai terutama saat musim kemarau. Perairan di daerah Lamongan dan Gresik sudah banyak dipengaruhi pasang surut air laut. Di situ juga banyak pertambakan untuk memelihara ikan bandeng dan mujair. Ikan-ikan tersebut seringkali lepas ke perairan umum. Sungai yang belum banyak mengalami modifikasi dan belum banyak mendapatkan tekanan, pencemaran ekosistem dapat mendukung lebih banyak keragaman jenis ikan, sebagai contoh di Sungai Musi terdapat lebih dari 130 jenis ikan (Utomo et al., 1993; Samuel et al., 2001), di Sungai Kapuas terdapat lebih dari 200 jenis ikan (Dudley, 1996), sedangkan Sungai Barito terdapat lebih dari 107 jenis ikan (Prasetiyo et al., 2003).

\section{Kegiatan Penangkapan}

Kegiatan penangkapan ikan di Bengawan Solo pada umumnya dilakukan dengan alat yang sederhana seperti jaring (gill net), jala (cast net), pancing (hook line), bubu (pot traps), cerok (scoop net), dan anco (lift net). Illegal fishing (kegiatan penangkapan yang dilarang) seperti stroom juga sering dilakukan. Sungai yang belum banyak mengalami modifikasi dan belum banyak mendapat tekanan ekosistem mempunyai kegiatan penangkapan yang lebih kompleks dengan alat yang sederhana sampai dengan ke yang besar. Sebagai contoh di Sungai Musi, Sungai Kapuas, Sungai Barito kegiatan penangkapan sudah menjurus ke komersial dengan menggunakan alat tangkap yang besar seperti tuguk (filtering device), hampang (barrier traps), selambau atau kilung (filtering net), ngesar (active seine), ngesek (active barrier), mangumpe (seine with agregating device), dan beje (pond traps). Alat tersebut dapat menangkap ikan dalam jumlah yang besar pada saat musim kemarau dapat mencapai 100 sampai dengan $300 \mathrm{~kg}$ per hari (Arifin, 1978; Hoggarth \& Utomo, 1994; Utomo \& Prasetiyo, 2004).

Nelayan di Gajah Mungkur sudah terorganisir, dan sudah ada kelompok nelayan. Penjualan ikan dilakukan di tempat pendaratan ikan yang berjumlah 5 unit, setiap hari rata-rata dapat mendaratkan ikan 300 sampai dengan $1.000 \mathrm{~kg}$. Produksi perikanan tangkap rata-rata $107 \mathrm{~kg}$ per ha per tahun (luas waduk 8.800 ha). Jumlah kelompok nelayan dan petani ikan ada 18 kelompok dengan jumlah total anggota 584 orang (Anonimus, 2003). Di samping nelayan, tiap hari banyak orang memancing di waduk atau di sungai yang keluar dari waduk, dengan rata-rata jumlah pemancing ada 20 sampai dengan 30 orang dengan hasil rata rata 0,5 sampai dengan $2 \mathrm{~kg}$. Penebaran ikan introduksi di Waduk Gajah Mungkur telah dilakukan oleh berbagai pihak antara lain Pemerintah Daerah Propinsi Jawa Tengah dan Pusat Riset Perikanan Tangkap (Tabel 4).

Kegiatan penangkapan di Waduk Gajah Mungkur didominasi oleh alat tangkap jaring (gill net) berukuran mata jaring 3 sampai dengan 7 inci. Jaring ukuran 3 sampai dengan 4 inci digunakan untuk menangkap ikan ukuran kecil sampai dengan sedang seperti ikan nila, tawes, nilem, Lukas, dan lain-lain, sedangkan jaring ukuran 5 sampai dengan 7 inci digunakan untuk menangkap

Tabel 4. Penebaran ikan di Waduk Gajah Mungkur Wonogiri

Table 4. Stocking in Gajah Mungkur reservoir at Wonogiri

\begin{tabular}{rllll}
\hline Tahun & \multicolumn{1}{c}{ Jenis ikan } & Jumlah (ekor) & \multicolumn{1}{c}{ Penebar } & Keterangan \\
\hline $1981-2003$ & Patin siam, nila, tawes & 593.000 & Pemda Jateng & \\
$1983-2003$ & Nila, tawes & 1.911 .000 & Pemda Jateng & \\
2003 & Jambal sius & 30.000 & PRPT & Untuk riset \\
\hline
\end{tabular}

Sumber/Sources: Anonimus, 2003 
ikan berukuran sedang sampai dengan besar seperti ikan sogo, jambal, dan betutu. Berdasarkan pada data blanko isian dari responden di Waduk Gajah Mungkur memperlihatkan bahwa hasil tangkapan pada musim kemarau dengan alat tangkap gill net didominasi oleh ikan nila, jambal, dan tawes (lihat Tabel 5). Musim penangkapan di Waduk Gajah Mungkur sepanjang tahun, dengan puncak musim mulai awal penghujan. Hasil tangkapan di Waduk Gajah Mungkur pada saat musim penghujan mengalami kenaikan dari $8,6 \mathrm{~kg}$ per hari per orang saat kemarau menjadi $17,50 \mathrm{~kg}$ per hari per orang saat musim penghujan, hasil tangkapan ikan jambal sius mengalami kenaikan yang berarti dari $28,8 \%$ saat kemarau menjadi $37,7 \%$ saat musim penghujan (Tabel 5 dan 6 ).

Akhir-akhir ini hasil tangkapan ikan nila dan jambal sius mengalami kenaikan sehingga menempati urutan ke-1 dan ke-2, bila dibandingkan penelitian Purnomo et al. (2003) mengatakan bahwa pada tahun 1999 hasil

Tabel 5. Hasil tangkapan jaring saat musim kemarau pada beberapa lokasi di Bengawan Solo

Table 5. Catch data of gillinet in dry season at some locations in Bengawan Solo River

\begin{tabular}{|c|c|c|c|c|}
\hline Lokasi & $\begin{array}{l}\text { Gajah Mungkur } \\
\text { (Wonogiri) }\end{array}$ & $\begin{array}{l}\text { Bendung Colo } \\
\text { (Sokoharjo) }\end{array}$ & $\begin{array}{l}\text { Cemeng } \\
\text { (Sragen) }\end{array}$ & $\begin{array}{l}\text { Ngablak } \\
\text { (Tuban) }\end{array}$ \\
\hline $\begin{array}{l}\text { Hasil tangkapan } \\
\text { (kg per hari per } \\
\text { orang) }\end{array}$ & 8,6 & 1,56 & 3,2 & 4,75 \\
\hline $\begin{array}{l}\text { Komposisi hasil } \\
\text { tangkapan (\%) }\end{array}$ & $\begin{array}{l}\text { Nila }(40,3) \\
\text { Jambal Sius } \\
(28,8) \\
\text { Tawes }(24,7) \\
\text { Sogo }(5,1) \\
\text { Lain-lain (1) } \\
\text { (Betutu dan } \\
\text { lukas) }\end{array}$ & $\begin{array}{l}\text { Tawes }(76,8) \\
\text { Sogo }(18,2) \\
\text { Nila }(2,3) \\
\text { Bloso }(2,7)\end{array}$ & $\begin{array}{l}\text { Sapu-sapu } \\
(90,4) \\
\text { Tawes }(5,1) \\
\text { Lain-lain }(2,5) \\
\text { (Daringan dan } \\
\text { wader) }\end{array}$ & $\begin{array}{l}\text { Wagal }(47) \\
\text { Wader }(20,1) \\
\text { Bader }(8,68) \\
\text { Keting }(6,62) \\
\text { Tagih }(5,3) \\
\text { Daringan }(5,81) \\
\text { Jambal lokal }(2,65) \\
\text { Bendol }(1,45) \\
\text { Lain-lain }(2,34) \\
\text { (Lumbet, lemper, } \\
\text { bandeng, betutu, dan } \\
\text { udang) }\end{array}$ \\
\hline
\end{tabular}

Keterangan/Remarks: Musim kemarau pada buian Mei sampai dengan Oktober 2004 (Dry season on May to October 2004)

Tabel 6. Hasil tangkapan jaring saat musim penghujan pada beberapa lokasi di Bengawan Solo Tablel 6. Catch data of gillnet in wet season at some location site in Bengawan Solo River

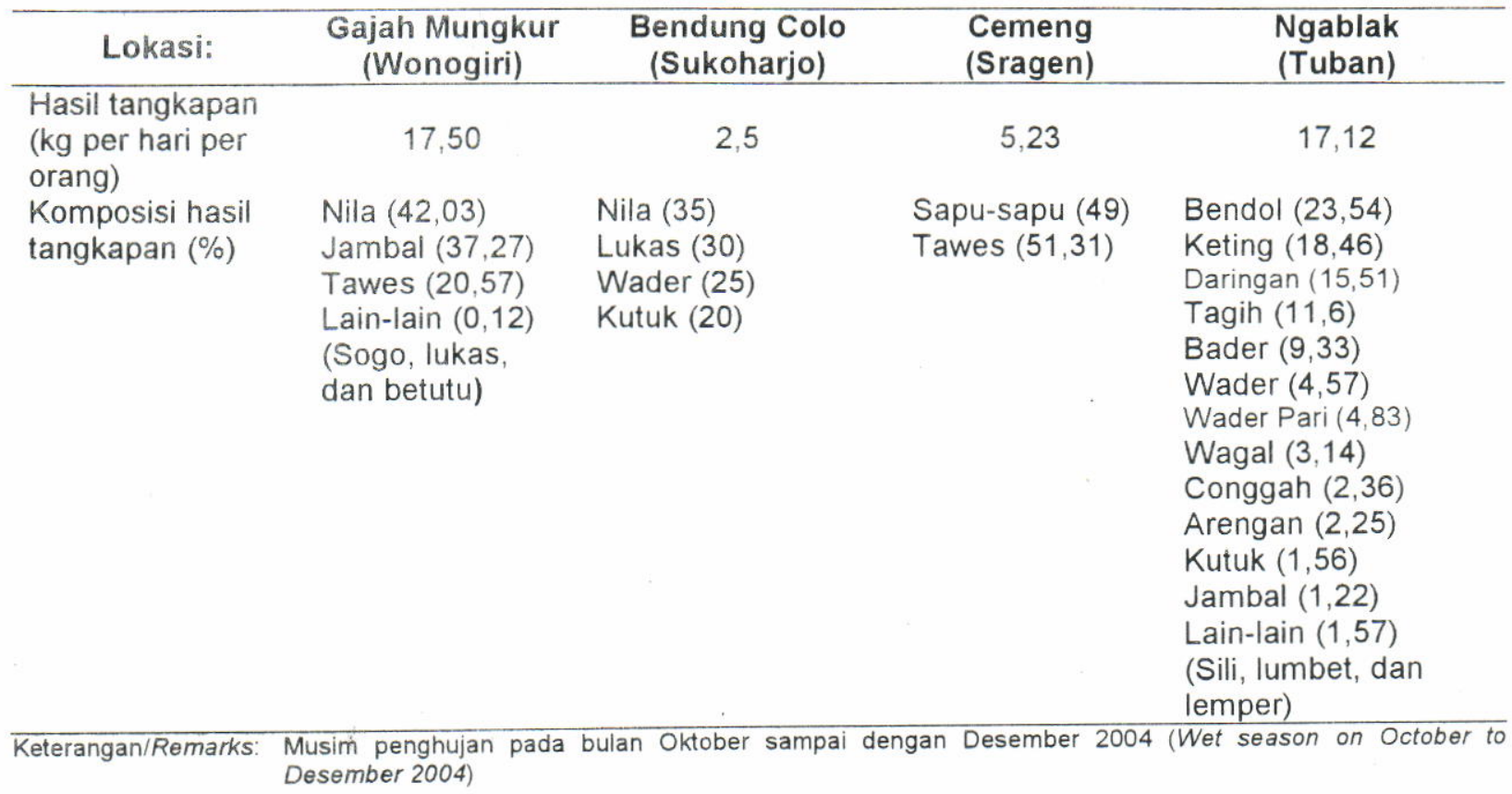


tangkapan ikan patin (jambal sius) menempati urutan ke-7 dan ikan nila urutan ke-9. Selanjutnya, dinyatakan oleh Purnomo et al. (2003) ikan jambal sius (Pangasius hypopthaimus) yang ditebar di Waduk Gajah Mungkur dapat berkembang dengan baik karena ketersediaan pakan alami (plankton, detritus) sangat mendukung. Berdasarkan pada wawancara dengan nelayan diperoleh informasi bahwa hasil tangkapan jambal sius dalam kurun waktu 3 tahun terakhir ini mengalami kenaikan.

Kegiatan penangkapan di stasiun pengamatan Bendung Colo (Sukaharja) tidak dilakukan sepanjang tahun tetapi hanya saat air besar datang dari hulu sungai. Alat yang digunakan adalah jala dan jaring. Sifat kegiatan penangkapan hanya sambilan dan dalam 1 tahun lama penangkapan hanya 2 sampai dengan 4 bulan. Berdasarkan pada data blanko isian dari nelayan responden di Bendung Colo memperlihatkan bahwa pada musim kemarau tahun 2004 hasil tangkapan didominasi oleh ikan tawes dan sogo (Tabel 5). Pada saat musim penghujan hasil tangkapan mengalami kenaikan dari $1,56 \mathrm{~kg}$ per hari per orang saat musim kemaru menjadi $2,5 \mathrm{~kg}$ per hari per orang saat musim penghujan (Tabel 5 dan 6). Pada stasiun pengamatan di Juruk, Solo tidak ada responden karena tidak ada nelayan, hanya kadang-kadang terlihat orang menjala ikan pada sore hari. Berdasarkan pada pengambilan contoh hasil tangkapan, diperoleh informasi bahwa mereka mendapatkan hasil $0,8 \mathrm{~kg}$ per hari dan terdiri atas ikan kutuk (60\%) dan mujair (40\%). Ikan yang tertangkap di bagian hilir Waduk Gajah Mungkur sampai dengan Solo kebanyakan merupakan ikan yang lepas dari Waduk Gajah Mungkur saat pintu air dibuka (tawes dan nila).

Kegiatan penangkapan di Desa Cemeng (Sragen) dilakukan sepanjang tahun dengan alat jala, jaring, dan sekali-kali dengan cerok apabila sedang ada ikan mabuk karena pencemaran air. Berdasarkan pada data blanko isian dari nelayan responden di Desa Cemeng memperlihatkan bahwa pada saat musim kemarau hasil tangkapan didominasi oleh ikan sapu-sapu (Tabel 5). Pada saat musim penghujan hasil tangkapan mengalami kenaikan $3,2 \mathrm{~kg}$ per hari per orang saat kemarau menjadi $5,23 \mathrm{~kg}$ per hari per orang saat musim penghujan, tangkapan ikan tawes mengalami kenaikan yang cukup berarti dari $5,1 \%$ saat kemarau menjadi $51,31 \%$ saat musim penghujan (Tabel 5 dan 6). Ikan sapu-sapu merupakan jenis ikan yang tahan terhadap pencemaran, namun harga tidak ekonomis sulit dipasarkan.

Kegiatan penangkapan di Desa Ngablak (Tuban) dilakukan sepanjang tahun dengan alat tangkap stroom, jaring, jala, dan serok. Jenis ikan lokal banyak tertangkap pada saat musim penghujan dan kemarau, jambal lokal ada walaupun jumlah sedikit. Penangkapan ikan ukuran besar seperti jambal dan sogo dilakukan di lubuk sungai terutama saat kemarau, karena lubuk mempunyai gua yang merupakan tempat perlindungan dan persembunyian ikan berukuran besar (Utomo \& Prasetiyo, 2004). Berdasarkan pada data blanko isian dari nelayan responden di Desa Ngablak memperlihatkan bahwa pada saat musim kemarau hasil tangkapan didominasi oleh ikan wagal, wader (Tabel 5). Pada saat musim penghujan hasil tangkapan mengalami kenaikan dari $4,75 \mathrm{~kg}$ per hari per orang saat kemarau menjadi $17,12 \mathrm{~kg}$ per hari per orang dengan didominasi oleh ikan bendol, keting, dan daringan (Tabel 5 dan 6).

Berdasarkan pada data dari hasil wawancara dengan nelayan di daerah solo dan Sragen diperoleh informasi bahwa pada kurun waktu 10 tahun terakhir hasil tangkapan ikan lokal seperti ikan sogo, bader atau tawes, dan wagal mengalami penurunan, sedangkan ikan sapu-sapu mengalami kenaikan. Ikan lokal tiap tahun cenderung mengalami penurunan. $\mathrm{Hal}$ ini, disebabkan oleh habitat asli telah banyak mengalami perubahan dan tidak pernah dilakukan penebaran kembali. Ikan sapu-sapu merupakan ikan yang tahan terhadap pencemaran. Pemakaian bahan organik terlihat pada stasiun pengamatan di Desa Cemeng, yaitu ditunjukkan oleh kualitas air buruk dan terindikasi sudah tercemar, ikan yang mendominasi adalah ikan sapu-sapu.

Alat tangkap utama di Waduk Gajah Mungkur yaitu jaring ukuran 2 sampai dengan 4 inci dan ukuran 5 sampai dengan 7 inci. Hasil tangkapan jaring ukuran 2 sampai dengan 4 inci didominasi oleh ikan tawes dan nila, sedangkan ukuran 5 sampai dengan 7 inci didominasi oleh ikan jambal sius dengan puncak musim pada musim penghujan (Tabel 7).

Alat tangkap utama di daerah Cemeng, Sragen yaitu jala dan jaring, ikan sapu-sapu mendominasi hasil tangkapan, terutama saat musim kemarau. Saat hujan datang sering ada ikan mabuk yang datang dari arah hulu melewati daerah Sragen yang sudah banyak terjadi pencemaran, ikan tersebut antara lain tawes. Untuk menangkap ikan yang sedang mabuk tersebut sering digunakan alat tangkap jala dan serok. Alat tangkap utama di daerah Ngablak, Tuban yaitu jaring dan stroom, jenis ikan yang tertangkap lebih beragam daripada di daerah tengah dan hulu, terutama ikan lokal (Tabel 7). 
Distribusi Jenis Ikan dan Kualitas...... di Bengawan Solo (Utomo A.D.,et al.)

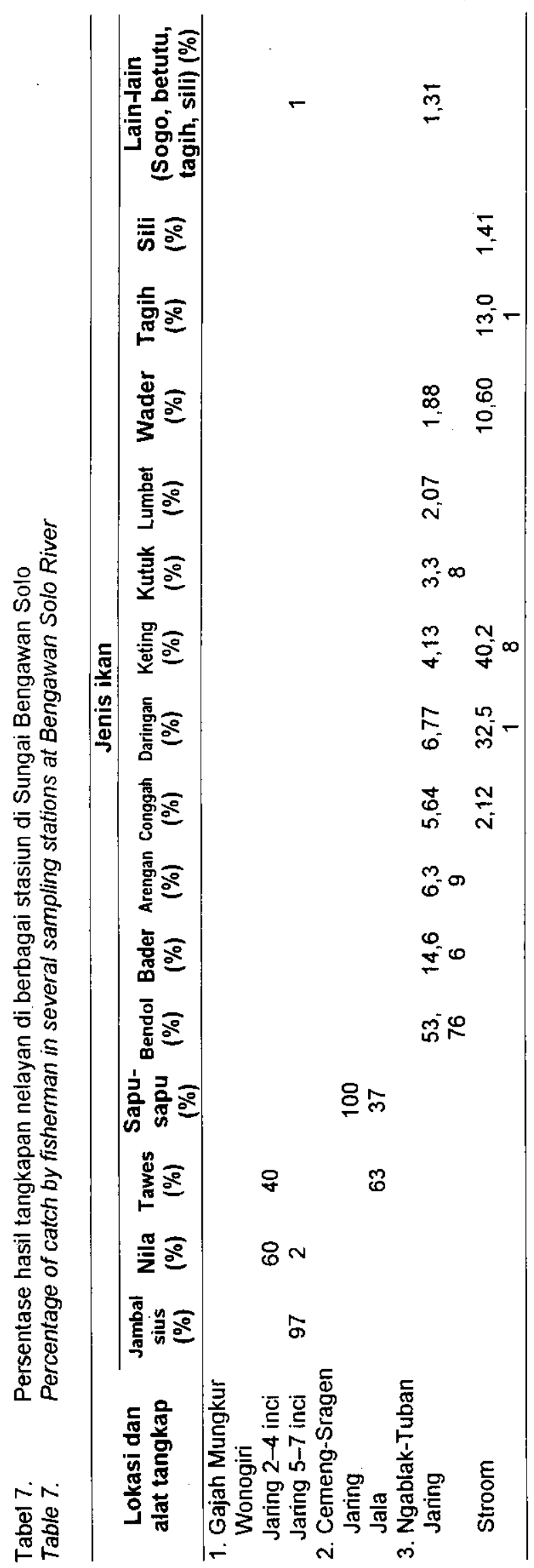




\section{KESIMPULAN DAN SARAN}

\section{Kesimpulan}

Kurang lebih ada 40 jenis ikan di Bengawan Solo. Jenis ikan tebaran (nila dan jambal sius) telah mendominasi hasil tangkapan di Waduk Gajah Mungkur Wonogiri (wilayah hulu). Perairan di Tenggak, Cemeng, dan Sragen (wilayah tengah) telah tercemar dengan indikasi oksigen rendah, karbondioksida tinggi, COD tinggi, fenol tinggi, dan minyak lemak tinggi. Perairan yang tercemar tersebut didominasi oleh ikan sapu-sapu. Di Perairan di Ngablak, Tuban, dan Bojonegoro (wilayah hilir) sering terdapat jenis ikan lokal yang bernilai ekonomis seperti jambal lokal, tagih, lumbet, lemper, wagal, dan lain-lain.

\section{Saran}

Agar dilakukan pelestarian dan rehabilitasi habitat spesifik (lubuk, sungai, rawa, dan jalur ruaya ikan) untuk melindungi ikan lokal yang sudah mulai langka seperti ikan patin lokal, tagih, lumbet, betutu, dan lain-lain. Selanjutnya, ditebari ikan lokal seperti ikan jambal lokal dan tagih. Agar dilakukan pengendalian pencemaran di Bengawan Solo dengan cara meningkatkan kesadaran bersama, pemantauan pembuangan limbah, dan penindakan bagi pelaku.

\section{DAFTAR PUSTAKA}

Anonim. 2003. Pengelolaan usaha perikanan di Waduk Gajah Mungkur Kabupaten Wonogiri. Dinas Kehewanan, Perikanan, dan Kelautan Kabupaten Wonogiri.

Anonim. 1992. Rencana pengelolaan lingkungan Waduk Wonogiri. Departemen Pekerjaan Umum. Pusat Penelitian Kependudukan dan Lingkungan Hidup Universitas Diponegoro. Semarang.

Anonim. 1997. Rencana pengelolaan lingkungan, rencana pemantauan lingkungan pada AMDAL perbaikan dan pengaturan Sungai Bengawan Solo bagian hilir. Direktorat Jenderal Pengairan. Departemen Pekerjaan Umum. Proyek Induk Pengembangan Wilayah Bengawan Solo.

APHA. 1981. Standard methods for the examinations of water and wastewater. APHA inc. Washington DC.

Arifin, Z. 1978. Beberapa aspek tentang penangkapan ikan di perairan lubuk lampam
Sumatera Selatan. Paper disampaikan dalam Simposium Modernisasi Perikanan Rakyat di Jakarta Tanggal 27 sampai dengan 30 Juni 1978. LPPD Cabang Palembang. 25 hal.

Dudley, R. G. 1996. The fishery of the Danau Sentarum wild life reserve West Kalimantan Indonesia. Asian Wetland Bureau (AWB). Bogor. $435 \mathrm{p}$.

Effendi, H. 2000. Telaah kualitas air bagi pengelolaan sumber daya dan lingkungan perairan. Buku Materi Kuliah pada Jurusan Manajemen Sumber Daya Perairan Fakultas Perikanan dan IImu Kelautan. Institut Pertanian Bogor. Bogor. 259 hal.

Gustiano, R. 2003. Taxonomy and Phylogeny of Pangasidae Catfishes from Asia (Ostariophysi, Siluriformes). Laboratory of Comparative Anatomy and Biodiversity. Katholieke Universiteit Leuven. Belgium. 296 p.

Hoggarth, D. D. \& A. D. Utomo. 1994. The fisheries ecology of lubuk lampam river floodplain in South Sumatera, Indonesia. International Journal Fisheries Research. Elsevier. London. $20(191-213)$.

Juhro, S. 1989. Komunitas ikan di Waduk Wonogiri Jawa Tengah. Skripsi. Institut Pertanian Bogor. Fakultas Perikanan. Jurusan Manajemen Sumber Daya Perairan.

Kottelat, M., A. J. Whitten, S. N. Kartikasari, \& S. Wirjoatmodjo. 1993. Freshwater fishes of western Indonesia and Sulawesi (ikan air tawar Indonesia bagian barat dan Sulawesi). Periplus Editions-Proyek EMDI. Jakarta.

Prasetiyo, D., Asyari, \& Rupawan. 2003. Keragaman jenis ikan di Sungai Barito. Laporan Teknis. Balai Riset Perikanan Perairan Umum Palembang.

Purnomo, K. 2000. Kompetisi dan pembagian sumber daya pakan komunitas ikan di Waduk Wonogiri. Jurnal Penelitian Perikanan Indonesia. Pusat Riset Perikanan Tangkap. Jakarta. 6 (3-4): 16-23.

Purnomo, K., E. S. Kartamihardja, \& S Koeshendradjana. 2003: Pertumbuhan, mortalitas, dan kebiasaan makan ikan patin siam (Pangasius hypopthalmus) introduksi di Waduk Gajah Mungkur. Jurnal Penelitian Perikanan Indonesia Edisi Sumber Daya dan Penangkapan. Pusat Riset Perikanan Tangkap. Badan Riset Kelautan dan Perikanan. Jakarta 9 (3): 13-21. 
Samuel, S. Adhie, \& Subagja. 2001. Inventarisasi dan distribusi biota serta karakteristik habitat Sungai Musi. Laporan Teknis. Balai Riset Perikanan Perairan Umum. Palembang.

Utomo A. D., Z. Nasution, \& S. Adjie. 1993. Kondisi ekologi dan potensi sumber daya perikanan Sungai Musi. Prosiding TKI Perikanan Perairan Umum. Pengkajian Potensi dan Prospek Pengembangan Perairan Umum Sumatera Selatan. Pusat Penelitian dan Pengembangan Perikanan. Jakarta.
Utomo, A. D. \& D. Prasetiyo. 2004. Evaluasi kegiatan penangkapan ikan di Sungai Barito, Kalimantan Tengah dan Selatan. Laporan Teknis. Balai Riset Perikanan Perairan Umum. Palembang.

Weber, M. \& De Beaufort. 1916. The fishes of the Indo Australian Archipelago. E. J Brill Ltd. Leiden. 2: 404 pp.

www. Liputan 6.com. 2004. Liputan 6.SCTV. Jakarta. 
Lampiran 1. Jenis ikan tebaran yang mendominasi di Waduk Gajah Mungkur Wonogiri Appendix 1. Introduced fish species which dominant at Gajah Mungkur Reservoir
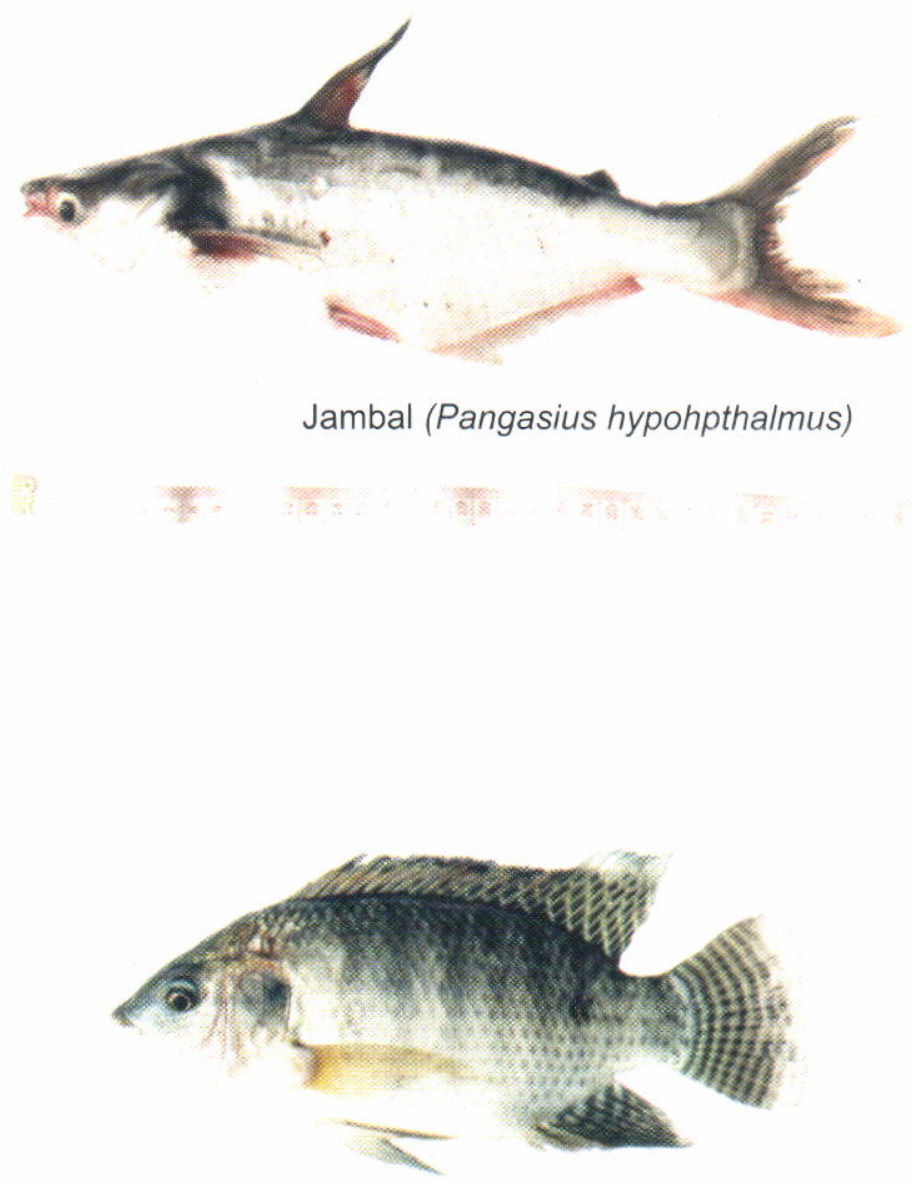

Nila (Oreochromis niloticus)
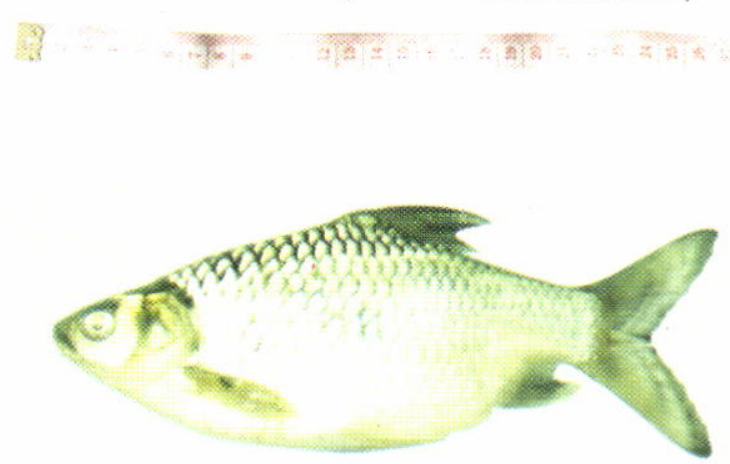

Tawes (Barbodes gonionotus) 

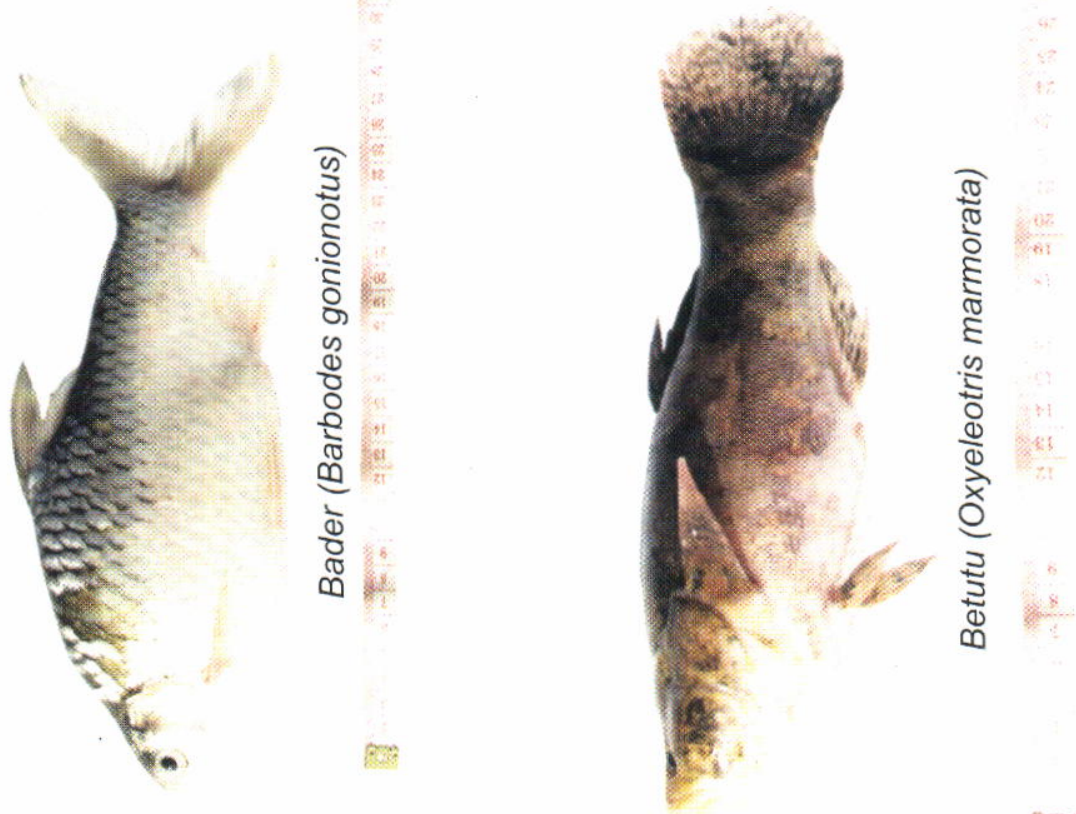

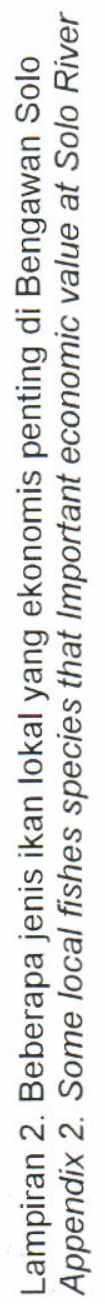
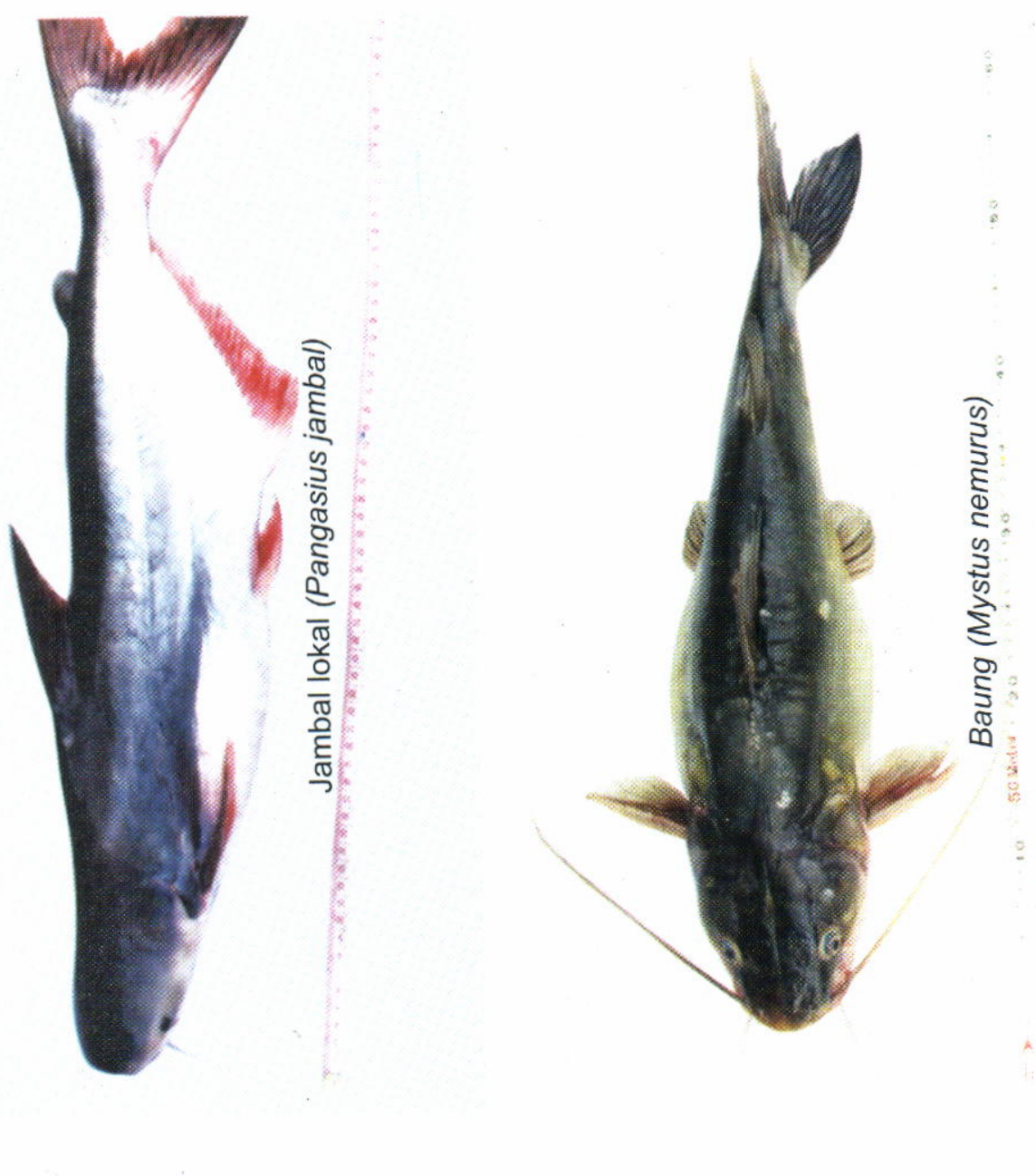
